\title{
ICT in Structured Programming Learning through Constructivist Techniques for Education
}

\section{Las TIC en el Aprendizaje de Programación Estructurada a través de Técnicas Constructivistas para la Educación}

\author{
Ingrid García Torres ${ }^{1, *}$, Angel Plaza Vargas ${ }^{1, \dagger}$, and Harry Zurita Hurtado ${ }^{1, \dagger}$ \\ ${ }^{1}$ Universidad of Guayaquil, Ecuador \\ \{ingrid.garciat,angel.plazav,harry.zuritah\}@ug.edu.ec
}

Received: August 15, 2017 — Accepted: September 15, 2017

How to cite: García Torres, I., Plaza Vargas, A., \& Zurita Hurtado, H. (2018). ICT in Structured Programming Learning through Constructivist Techniques for Education. Journal of Science and Research: Revista Ciencia e Investigación, 3(CITT2017), 69-71. https://doi.org/10.26910/ issn.2528-8083vol3issCITT2017.2018pp69-71

\begin{abstract}
There are some things for university students that are important to acquire the whole learning of a particular subject moreover when the subject is one of the last ones that a student must take in order to finish the university requirements to be a professional, at the moment the student has a wide range of knowledge and he is almost ready to begin his professional life. In the process of learning Structured Programming, it is necessary the use of teaching techniques that let students get thoroughly involved in building programs efficiently. This is the case of pedagogical focus based on the constructivism methodology with a pedagogical strategy solving problems and learning with a metacognition orientation based on the successful education for Structured Programming specifically, using programming languages like $\mathrm{C}++$, Visual Basic 6, Visual Basic Net, hypertext protocol, Java, among others. It should be mentioned that the main objective of this research is to develop a study with Learning Methodologies for Structured Programming using constructivist techniques. The specific objectives are based on establishing teaching events in the processes of meaningful learning of students; defining the percentage that teachers involved technologies in their classroom processes in terms of programming, classifying teachers into levels of knowledge about using constructivist programming technologies for teaching. Teachers should positively have as a part of his profile the knowledge of ICT in terms of software creation and the use of methodologies and resources doing teachers' role.
\end{abstract}

Keywords-ICT, Learning, Programming, Techniques, Constructivists.

Resumen - Hay algunas cosas para los estudiantes universitarios que son importantes para adquirir el aprendizaje completo de un tema en particular más cuando la materia es una de las últimas que un estudiante debe tomar para completar los requisitos universitarios para ser un profesional, en ese momento el alumno tiene una amplia gama de conocimientos y está casi listo para comenzar su vida profesional. En el proceso de aprendizaje de programación estructurada es necesario el uso de técnicas de enseñanza que permiten a los estudiantes para obtener todo involucrado en programas de desarrollo de manera eficiente. Este es el caso de pueda dar el enfoque basado en la metodología del constructivo activismo con estrategia de solución de problemas y el aprendizaje con una orientación de la meta cognición en base a la educación exitosa para la programación estructurada específicamente, utilizando el lenguaje de programación s como $\mathrm{C}++$, Visual Basic 6, Visual Basic Net, protocolo de hipertexto, Java, entre otros. Cabe mencionar que el objetivo principal de esta investigación es desarrollar un estudio con Metodologías de Aprendizaje para Programación Estructurada utilizando técnicas constructivistas. Los objetivos específicos se basan en el establecimiento de eventos de enseñanza en los procesos de aprendizaje significativo de los estudiantes; definir el porcentaje que los profesores involucran d las tecnologías en sus procesos de clase en términos de programación, clasificar a los docentes en niveles de conocimiento sobre utilizando tecnologías de programación constructivista para la enseñanza. Los docentes positivamente deben tener como parte de su perfil el conocimiento de las TIC en términos de creación de software y el uso de metodologías y recursos que hacen el papel de los profesores.

Palabras Clave-TICs, Aprendizaje, Programación, Técnicas, Constructivista.

\section{INTRODUCCIÓN}

$\mathbf{S}$ tructured programming is a subject of programming specialization, it consists in building easy handling programs. This subject is especially useful when there are some corrections or modifications that are necessary after a program or application has been created. By using structured

\footnotetext{
* Magister en Educacion Informática

† Master Universitario en Modelado Computacional en Ingeniería

$\dagger$ Master en Sistemas de Información
}

programming, it is much easier to understand the coding of the program, which has been done sequentially in different stages. An operation is proposed as an integrated whole and it is divided into simpler or less complex segments. Once all segments of the program are finished, the applications made by the programmers' pool are integrated. If structured programming has been used properly which must be simple and easy to be integrated and it suddenly presents a problem, it will be quick to detect it for its correction. The graphical representation of the structured programming is done through 
flow diagrams which represent the program with its inputs, processes, and outputs. The incorporation of ICT in higher education still faces big challenges; the empirical experience has shown that its instrumentalization is performed through routine practices, where the technical aspect of pedagogy is privileged. It is not enough to get teachers and students to access ICT, the most important aspect is the effective and efficient use of ICTs and incorporates them naturally into academic practices. This depends on the effectiveness and efficiency of the teaching-learning processes; as well as the capacities of the students involved and their interactions with electronic resources in the classroom (Hernández et al., 2014).

\section{DEVELOPMENT}

\section{Information and Communication Technology}

Nowadays there is no a system to follow-up the planning of a class that requires the incorporation of the use of ICT in all the syllables of a higher institution or an evaluation of the usage of it in the classrooms, then the use of the technologies of Information and communication in their interlearning processes is at the teachers' criterion even more the Structured Programming subject. For this reason, only a low percentage of teachers have incorporated ICTs into their processes in a class, depriving students of the advantages of using ICTs.

The main cause that we have at this institution is that teachers that have tenure for many years do not have an educational system that incorporates Information Technologies and the Communication Systems.

Teachers do not have the habit to be trained in using ICTs. Teachers will be able to know the subject, but the use of ICTs in the Structured Programming subject is not demonstrated. The lack of infrastructure is essential in the case of teaching because Structured Programming is a subject that needs to be practiced and needs exercises to be done not only at home but in the class as well.

Another issue is that the training in the market is not specialized in training; the way of teaching certain subjects are based just on indicating appropriate positions to teach the class, but not the modality for certain practical subjects such as Structured Programming.

\section{The Andragogy}

Andragogy is the science that studies the different forms of adult learning. The ancient Hebrew prophets and Jesus in biblical times had been masters of adults, not children. The Greeks and Romans perfected teaching methodologies, encouraging learning through processes of inquiry and discussion (Figuero, 2013).

\section{Constructivism}

The effects and introversions made on the initial determination of this research sent us to the projection, design, and elaboration of didactic strategies with a constructivist approach to the teaching of the programming, based on the cognitive theories of learning.

\section{Structured Programming}

It is a paradigm of programming oriented to improve the clarity, quality and time of development of a computer program, using only subroutines and three structures: sequence, selection (if and switch) and iteration (loops for and while), considering unnecessary and counterproductive The use of unconditional transfer instruction (GOTO), which could lead to "spaghetti code", which is much more difficult to follow and maintain, and was the cause of many programming errors (EcuRed, 2010).

There is a lot of talk about "active learning" ... but is not "interactive learning" really what we want to promote in the student? (Raul Santiago, 2016).

\section{OBJECTIVES}

\section{General objective}

To develop a study with learning methodologies for the subject Structured Programming using constructivist techniques.

\section{Specific objectives}

- Establish teaching events in meaningful student learning processes. Define in what percentage teachers involve the technologies in their classroom processes in terms of programming.

- Classify teachers in levels of knowledge the use of programming technologies for teaching.

\section{Methodology}

According to the psychological and epistemological foundation, the pillars that constitute the didactic proposal under a constructivist approach and the proposed objectives, the sequence of the same was structured in four stages:

1) Exploration Stage: The characteristics of the students were analyzed from the cognitive point of view, their previous knowledge, their behavior, their affectionate state, and the way in which it unfolds, represented the beginning of teaching planning creating new contents, from the simplest contents to the most complicated ones, and the statement of appropriate strategies to the student's cognitive level, establishing a process of socio-affective interaction between the teacher and his students, sharing their different expectations, concerns, and points of view.

At this stage, relevant evaluation tools and techniques were used in order to obtain information from simple informal evaluation tests to tests for evaluation of previous learning, interview guidelines, questionnaires, and the Socratic procedure.

2) Presentation Stage: The development of the topics reached an inductive process of meaning construction, whose origin is located in the initial and daily ideas that the student has on the contents of programming, encouraging both practical and analytically active participation. This activity was achieved by the training of the institution for teachers and in the complementary tutorials so that the presentations are positive in teaching. 
Students were motivated in the process. Group activities were incorporated and they forged disputes and debates on the definitions of basic topics of the contents, in order to get to the understanding of the different activities to relate to the programming.

3) Cognitive Evaluation Stage: At this stage, it was verified through interviews and activities and monitoring of activities to observe the degree of assimilation and adaptation that the students had reached in which the teacher found through surveys the degree of understanding that the students had about the aspects developed during class. This process was carried out by the teacher who established the basis for the student to learn and to learn through strategies that allow him to self-assess and establish his weaknesses, strengths, and aspects to improve the level of learning achieved.

4) Projection Stage: In this last stage, it was projected with the purpose of being put to the students to new conditions where it could apply different logics as far as the programming and tactics of actual obtained lessons and, in this way, to found new useful knowledge, generating in this way a critical, reflective and creative though by the student (see Figure 1).

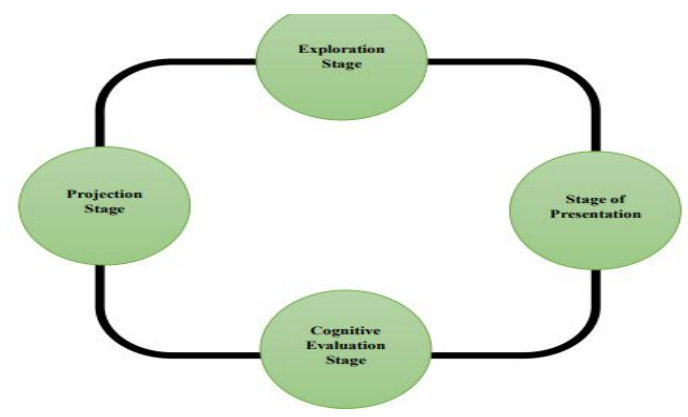

Figure 1. Methodology - Stages.

Source: Prepared by the authors.

\section{CONCLUSION}

- It is an advice to progressively incorporates a simple and functional programming language into the didactic process.

- Applying the inductive reasoning to activate the notions and logic to be able to program and lead successively the student towards the scientific conceptualization of programming knowledge.

- Developing and applying strategies in the resolution of problems that promote deductively reasoning and understanding of structures.

- To establish a social climate of the flexible and dynamic classroom, analyzing from the perspective of the social interaction between teacher and student, through communication and contribution.

- Directing the evaluation process towards integral and balanced assessment as a foundation for the academic, personal and socio-affective growth of the students in the steps to be programmed.

\section{BIBLIOGRAPHIC REFERENCES}

EcuRed (2010). Programacion estructurada.

Figuero, N. (2013). Fundamentos de Andragogía.

Hernández, L., Acevedo, J., Martínez, C., and Cruz, B. (2014). El uso de las tic en el aula: un análisis en términos de efectividad y eficacia. In Congreso Iberoamericano de Ciencia, Tecnología, Innovación y Educación.

Raul Santiago (2016). Del aprendizaje activo al aprendizaje interactivo. 